\title{
ALVARADOA AMORPHOIDES GERMINATION AT LOW WATER POTENTIAL AND THE ROLE OF THE ANTIOXIDANT SYSTEM
}

\author{
Verónica Hernández-Pérez ${ }^{1}$, Judith Márquez-Guzmán², Sobeida Sánchez-Nieto \\ and Rocío Cruz-Ortega ${ }^{1,4}$ \\ ${ }^{1}$ Instituto de Ecología, Departamento de Ecología Funcional, Universidad Nacional Autónoma de México, \\ México, D.F., Mexico \\ ${ }^{2}$ Facultad de Ciencias, Laboratorio de Desarrollo de Plantas, Universidad Nacional Autónoma de México, \\ México, D.F., Mexico \\ ${ }^{3}$ Facultad de Química, Departamento de Bioquímica, Universidad Nacional Autónoma de México, \\ México, D.F., Mexico \\ ${ }^{4}$ Author for correspondence: Rocío Cruz-Ortega: rcruz@ecologia.unam.mx
}

\begin{abstract}
Tropical dry forests are characterized by a high diversity of tree communities and extremely heterogeneous water availability. The tree Alvaradoa amorphoides is a pioneer species of the tropical dry forest found in Xochicalco, Morelos, Mexico. To determine the water requirements for this species to germinate, we evaluated the seed germination rates under field and laboratory conditions. In the field, the seeds had an overall mean germination rate of $42 \%$, but the rate varied between the different sites independent of the soil relative humidity and landscape. Alvaradoa amorphoides seeds exposed to a water potential of -0.5 MPa delayed germination, extending Phase II. At the -1.0 and $-1.5 \mathrm{MPa}$ water potentials, germination was inhibited by 80 and $100 \%$, respectively, but the seeds remained viable. Although, the oxygen consumption did not differ between the treatments, the respiration profiles did not show the same triphasic curve as the control. The $\mathrm{H}_{2} \mathrm{O}_{2}$ and $\mathrm{O}_{2}$ - levels were not significantly different in the seeds at the evaluated low-water potentials (-0.5 and -1.0 MPa), nor were the catalase, superoxide dismutase, and glutathione reductase activity. Only ascorbate peroxidase activity was inhibited at these two water potentials. Our data showed that the A. amorphoides seeds remained in phase II during low water potentials without high levels of Reactive Oxygen Species (ROS) [AR1] production and continued to be viable; this latter fact might explain the low influence of the humidity and landscape on the germination performance in the field.
\end{abstract}

Key words: Alvaradoa amorphoides, antioxidant system, germination, low water potential, Xochicalco.

Resumen: Alvaradoa amorphoides es un árbol representativo de la Selva Baja Caducifolia de la zona de Xochicalco en el Estado de Morelos, México. En este trabajo se evaluaron los requerimientos hídricos para la germinación de esta especie, tanto en campo como en laboratorio. En campo se evaluó la germinación en sitios con diferente geomorfología y características de humedad. En laboratorio se evaluó el porcentaje de germinación, imbibición, respiración y actividad de enzimas antioxidantes en semillas colocadas en soluciones de diferente potencial hídrico. El porcentaje de germinación en campo fue de $42 \%$, pero fue diferente entre sitios independientemente de la humedad relativa y de la geomorfología del suelo. Las semillas expuestas a - $0.5 \mathrm{MPa}$ retrasaron su germinación, extendiendo la fase II de la germinación. Los potenciales de -1.0 y $-1.5 \mathrm{MPa}$ inhibieron la germinación 80 y $100 \%$, respectivamente; sin embargo, las semillas permanecieron viables. El consumo de oxígeno no varió en las semillas expuestas a los diferentes potenciales hídricos, aunque sí su perfil respiratorio, ya que no mostraron las tres fases características. Los niveles de $\mathrm{H}_{2} \mathrm{O}_{2} \mathrm{y} \mathrm{O}_{2}^{-}$, y la actividad de catalasa, superóxido dismutasa y glutatión reductasa no fueron significativamente diferentes entre los potenciales hídricos probados (-0.5 y -1.0 MPa), solo la actividad de la ascorbato peroxidasa fue inhibida. Los resultados muestran que las semillas de A. amorphoides permanecen en fase II de la germinación en potenciales hídricos negativos, sin presentar niveles altos de especies reactivas [RC2] de oxígeno (ERO) y permaneciendo viables, [AR3] lo que podría explicar por qué el porcentaje de germinación no se vio afectado por la geoforma y la humedad en condiciones de campo.

Palabras clave: Alvaradoa amorphoides, germinación, potencial hídrico negativo, sistema antioxidante, Xochicalco.

T ropical dry forests represent $42 \%$ of all tropical forests worldwide (Murphy and Lugo, 1986; Janzen, 1988). This ecosystem is one of the most threatened, and it is vul- nerable due to increasing deforestation for agricultural and livestock activity, as well as human settlement (Trejo and Dirzo, 2000; Khurana and Singh, 2001). Tropical dry forests 
are characterized by a high diversity of tree communities and heterogeneous resource availabilities for water, nutrients, and light, among others. This ecosystem also shows a pronounced seasonality in rainfall, with two to six months of drought each year (Bullock and Solis-Magallanes, 1990; Khurana and Singh, 2001), and this seasonality affects the patterns of seed production, germination, survival, and seedling development. Water availability in these ecosystems affects the germination patterns (Garwood, 1983) and is considered one of the most important factors in modifying the structure and dynamics of this community (Murphy and Lugo, 1986). In a tropical dry forest, the soil water potential in the dry season can achieve up to $-1.5 \mathrm{MPa}$ (Engelbrecht et al., 2006). The majority of species produces and disperses seeds in the dry season before reliable rains begin, which then allows them to germinate when the soil humidity is optimal (Baskin and Baskin, 1998; Ceccon et al., 2006). Some species can germinate at low water potentials, such as Acacia senegal (-1.4 MPa), A. tortilis (-1.0 MPa), Leucaena leucocephala -1.6 MPa), Cassia obtusifolia (-0.5 MPa), and C. occidentalis (-0.5 MPa; Khurana and Singh, 2001).

Alvaradoa amorphoides, a tree in the Picramniaceae family (formerly in Simaroubaceae), is well represented in the tropical forest area of Xochicalco in Morelos, Mexico. This tree not only contributes to the structure of the community, but it is also used as firewood by the local people (Ceccon and Hernández, 2009). The A. amorphoides seed has a membranous seminal coat that is permeable to water (Salazar and Soihet, 2001). This particular characteristic suggests the seeds might have tolerance mechanisms that allow them to germinate under water-stress conditions. Germination is one of the most vulnerable processes and can be inhibited or delayed by several environmental factors, of which water stress is the most important. Seed germination begins with water uptake, and for this to occur, the soil humidity must be optimal (Hegarty and Ross, 1978; Bewley and Black, 1985). Metabolic processes such as mitochondrial respiration, which is associated with reactive oxygen species (ROS) production, are reactivated after imbibition (Bailly, 2004; Bailly et al., 2008). A similar increase in ROS generation has been shown under different types of stress, especially drought and salinity stress, with the mitochondria as the primary organelle affected (Xiong et al., 2002; Miller et al., 2010). Under natural conditions, A. amorphoides seeds need to cope with variable water availability; thus, the seeds might tolerate water stress and germinate by adjusting the activity of their antioxidant system.

The objective of this study was to evaluate seed germination in Alvaradoa amorphoides under field and laboratory conditions to determine the species' water requirements. In the laboratory, we exposed seeds to low water potentials and examined their germination rate, water uptake, and respiration. We also examined antioxidant enzyme activity to determine whether the antioxidant system plays a role during the germination process.

\section{Materials and methods}

Field site and environmental data. The study was conducted in a tropical dry forest located in the Xochicalco archeological zone of the Miacatlan region in Morelos, Mexico (18 $48^{\prime} 14^{\prime \prime} \mathrm{N}$ and $99^{\circ} 17^{\prime} 46^{\prime \prime} \mathrm{W}$ ). We recorded the environmental conditions (temperature and humidity) at the field site in 2009 through the use of data loggers (Onset Computer Corporation, USA) at four different locations. Additional data regarding annual precipitation was obtained from the nearest weather station at Zacatepec, Morelos (INIFAPCEZCA; Figure 1).

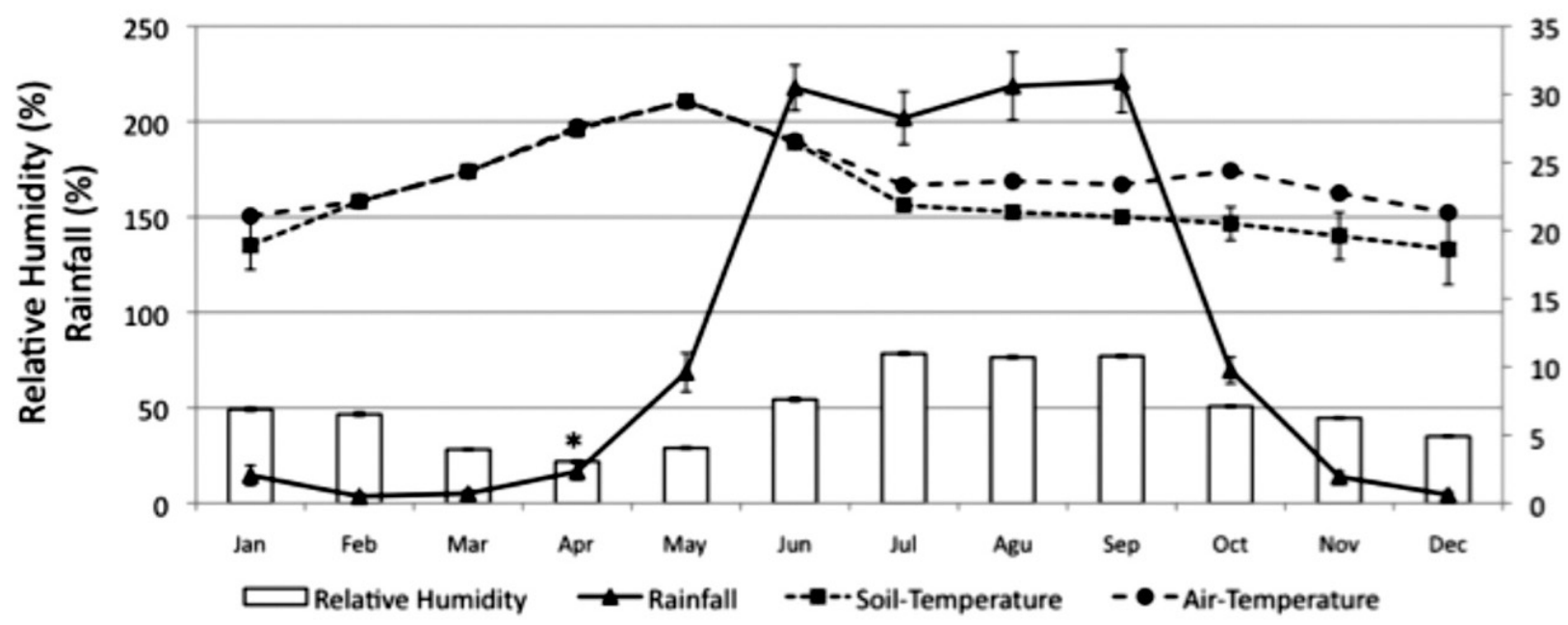

35 30 25 20

Figure 1. Meteorological data collected during 2009 in the Xochicalco archeological zone in Morelos, Mexico. Asterisk shows the month of seed collection. Rainfall or annual precipitation was obtained from the Zacatepec meteorological station in Morelos (INIFAP-CEZACA) and represents the mean precipitation from 1952 to 2005. 


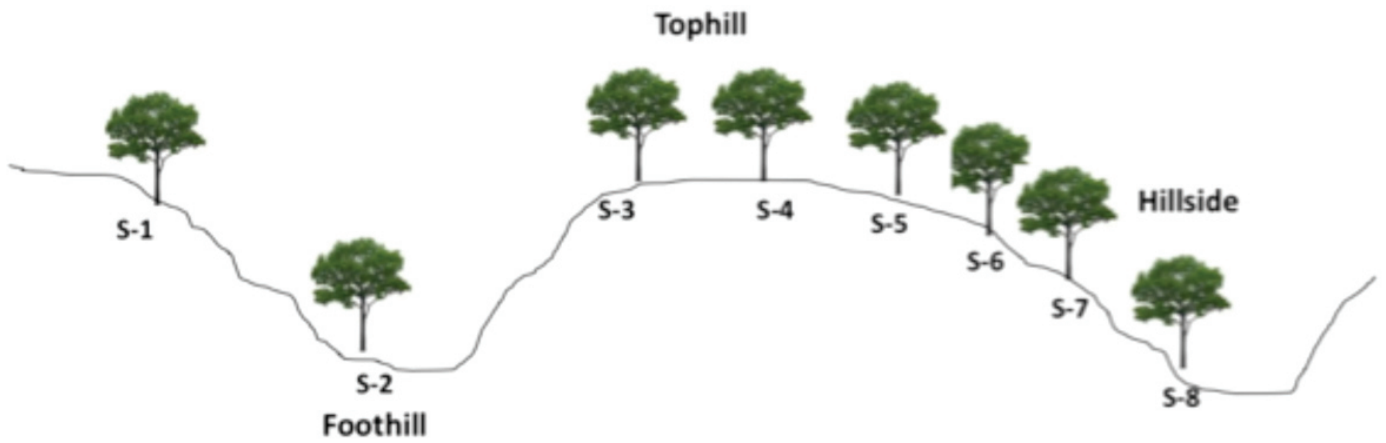

Figure 2. Geomorphology or landscape of the site in the Xochicalco archeological zone in Morelos, Mexico. The eight Alvaradoa amorphoides trees (S1 to S8) are represented; seeds were sown north, south, east, and west from the center of each trunk.

Seed germination at the field site. Eight individual Alvaradoa amorphoides trees were selected based on their distribution at the site to evaluate the seed germination rates in the field and make comparisons with the seed rain patterns for this species and zone as reported by Ceccon and Hernández (2009). The eight trees were located in different geomorphologies or landscapes, such as foothills or depressions, hillsides, and hilltops, each of which is characterized by different soil humidity conditions or water potentials throughout the year (Table 1). The seeds were collected in April 2009 and sown in the field at the beginning of the rainy season (June) as follows: Fifty seeds were placed inside organza or silk fabric bags, and four bags were sown at a depth of 0.5 to $1 \mathrm{~cm}$ and $2 \mathrm{~m}$ apart to the north, east, south, and west of the center of the trunk, for a total of 200 seeds per tree (Figure 2). The seeds were left for one month, and then germination was recorded to determine the mean germination rate $(\%)$ per site. The mean length and width of 100 A. amorphoides seeds was also determined, with the image analysis program WinFOLIA (Regent Instruments Canada Inc., Canada), which was $0.53 \pm 0.0043 \mathrm{~cm}$ and $0.2135 \pm$ 0.002359 , respectively.
Soil relative humidity. Soil samples were collected with a $100 \mathrm{~mL}$ soil corer to determine the soil humidity at each of the different landscapes. Three samples were collected at $1,1.5$, and $2 \mathrm{~m}$ to the north, east, south, and west of the trunk of each of the eight Alvaradoa amorphoides trees and placed in a cooler for transport. The fresh weight was determined on arrival at the laboratory, after which the samples were dried in an oven at $105^{\circ} \mathrm{C}$ for $24 \mathrm{~h}$. The dry weight was determined, and the relative humidity (RH) was calculated as described by Siebe et al. (1996) with the formula $\mathrm{RH}(\%)=((\mathrm{W} 1-\mathrm{W} 2) / \mathrm{W} 2) \times 100$, where $\mathrm{W} 1$ is the initial weight $(\mathrm{mg})$ and $\mathrm{W} 2$ is the final or dry weight $(\mathrm{mg})$. The data are reported as the soil $\mathrm{RH}(\%)$.

Seed germination in the laboratory at different water potentials. Three negative water potentials were used to perform an in vitro evaluation of the effects of stress water potential on Alvaradoa amorphoides seed germination: $-0.5,-1.0$, and -1.5 MPa. Polyethylene glycol (PEG 8000, Sigma) solutions were prepared based on the solute potential as calculated by the software SPMM (Michel and Radcliffe, 1995), with the program for molar-molal-g-solute/g water conversion. Twenty seeds were placed in Petri dishes containing $5 \mathrm{~mL}$

Table 1. Germination rates and soil relative humidity at the sites of eight individual Alvaradoa amorphoides trees and their corresponding landscape, slope, and the soil depth at which the seeds were sown. *Mean of 12 replicates \pm standard error; ${ }^{* *}$ period on germination was evaluated. Mean annual relative humidity was calculated from the five samples taken throughout the year.

\begin{tabular}{|c|c|c|c|c|c|c|c|c|c|c|}
\hline \multirow[t]{2}{*}{ Site } & \multirow[t]{2}{*}{ Land shape } & \multirow{2}{*}{$\begin{array}{l}\text { Slope } \\
\left({ }^{\circ}\right)\end{array}$} & \multirow{2}{*}{$\begin{array}{l}\text { Soil depth } \\
\text { (cm) }\end{array}$} & \multicolumn{3}{|c|}{ Germination } & \multicolumn{4}{|c|}{$\%$ of Soil Relative Humidity* } \\
\hline & & & & $\%$ & Mar & Jun & Jul** & Sep & Jan & Annual \\
\hline 1 & Side hill & 12 & 5.04 & 45 & $16 \pm 2$ & $52 \pm 3$ & $49 \pm 4$ & $83 \pm 7$ & $9 \pm 1$ & 45 \\
\hline 2 & Foot hill & 2 & 2.73 & 63 & $17 \pm 1$ & $40 \pm 2$ & $46 \pm 4$ & $69 \pm 2$ & $13 \pm 4$ & 46 \\
\hline 3 & Side hill & 12 & 2.17 & 61 & $16 \pm 1.2$ & $46 \pm 2$ & $50 \pm 2$ & $69 \pm 2$ & $11 \pm 1$ & 50 \\
\hline 4 & Top hill & 4 & 1.41 & 32 & $12 \pm 1$ & $36 \pm 3$ & $46 \pm 2$ & $63 \pm 4$ & $10 \pm 1$ & 46 \\
\hline 5 & Top hill & 4 & 1.41 & 60 & $16 \pm 1$ & $25 \pm 1$ & $23 \pm 2$ & $42 \pm 3$ & $4 \pm 1$ & 23 \\
\hline 6 & Side hill & 11 & 1.41 & 35 & $8 \pm 1$ & $31 \pm 3$ & $28 \pm 4$ & $54 \pm 4$ & $8 \pm 1$ & 28 \\
\hline 7 & Side hill & 11 & 1.41 & 9 & $5 \pm 1$ & $50 \pm 5$ & $59 \pm 4$ & $86 \pm 5$ & $14 \pm 1$ & 59 \\
\hline \multirow[t]{2}{*}{8} & Side hill & 17 & 0.65 & 21 & $11 \pm 1$ & $42 \pm 2$ & $41 \pm 1$ & $63 \pm 2$ & $9 \pm 4$ & 41 \\
\hline & Total mean & & & 42 & $13 \pm 1$ & $42 \pm 6$ & $43 \pm 1$ & $67 \pm 2$ & $10 \pm 1$ & \\
\hline
\end{tabular}


of the water potential solutions or distilled water as a control. The experimental design was randomized with eight replicates per treatment. The Petri dishes were placed in a growth chamber (Conviron, G30, Canada), at $27{ }^{\circ} \mathrm{C}$ with a 12:12 $\mathrm{h}$ photoperiod. The data are presented as germination rates, with a seed defined as having germinated when the radicle length reached 1 to $2 \mathrm{~mm}$.

Water uptake by seeds at different water potentials. To monitor the water uptake, the seeds were exposed to the water potentials as described above. Twenty-five seeds were placed in Petri dishes containing $5 \mathrm{~mL}$ of the PEG solutions. At $0,6,12,48,72,96$, and $170 \mathrm{~h}$, independent seed samples were removed with four replicates per time point and treatment, and their fresh weight was estimated. The seeds were then immediately placed in an oven for drying at $105^{\circ} \mathrm{C}$ for $24 \mathrm{~h}$ or until their weight was constant. The water uptake (the difference between fresh and dried weight) was calculated as described by Krishnan et al. (2004) with the formula $((\mathrm{W} 1-\mathrm{W} 2) / \mathrm{W} 2) \times 100$, where $\mathrm{W} 1$ is the initial weight $(\mathrm{mg})$ and $\mathrm{W} 2$ is the final or dried weight $(\mathrm{mg})$. The data are reported as RH (\%).

Oxygen consumption during germination. Oxygen consumption was evaluated $6,12,24,48$, and $96 \mathrm{~h}$ after the seeds imbibed the different water potential solutions. After placing 25 seeds in each Petri dish containing $5 \mathrm{~mL}$ of solution, they were placed in a growth chamber (Lab-Line Instruments, Inc., USA) at $27^{\circ} \mathrm{C}$ in the dark for the treatment period. For each time point, the oxygen uptake was monitored at room temperature with a Clark-type electrode connected to a biological oxygen monitor (YSI Oxygraph Model 5300; Yellow Spring Instruments, USA) by transferring each 25 seed sample and $5 \mathrm{~mL}$ treatment solution to the monitoring chamber and maintaining constant stirring. Three replicates were performed for each time point and treatment. The data are presented as $\eta$ atoms of oxygen seed ${ }^{-1}$ hour $^{-1}$.

ROS production and antioxidant enzyme activity during Alvaradoa amorphoides seed germination at different water potentials. All spectrophotometric analyses were conducted with a Varian spectrophotometer (Varian Australia Pty Ltd., Australia).

$\mathrm{H}_{2} \mathrm{O}_{2}$ content. The $\mathrm{H}_{2} \mathrm{O}_{2}$ was measured colorimetrically as described by Jana and Choudhuri (1982). After pulverizing the treated seeds in liquid nitrogen, the $\mathrm{H}_{2} \mathrm{O}_{2}$ was extracted by homogenizing $50 \mathrm{mg}$ of the ground seeds with $50 \mathrm{mM}$ phosphate buffer $(\mathrm{pH} 6.5 ; 1: 3 \mathrm{w} / \mathrm{v})$. The homogenate was centrifuged at $6,000 \times \mathrm{g}$ for $10 \mathrm{~min}$, and $1.0 \mathrm{~mL}$ of the supernatant was mixed with $1 \mathrm{~mL}$ of $0.1 \%$ titanium sulfate in $20 \% \mathrm{H}_{2} \mathrm{SO}_{4}(\mathrm{v} / \mathrm{v})$. After centrifuging the mixture, again at $6,000 \times \mathrm{g}$ for $10 \mathrm{~min}$, the yellow intensity was measured at $410 \mathrm{~nm}$. An extinction coefficient of $0.28 \mu \mathrm{mol}^{-1} \mathrm{~cm}^{-1}$ was used to calculate the $\mathrm{H}_{2} \mathrm{O}_{2}$ level, which is expressed as $\mu \mathrm{mol}$ $\mathrm{H}_{2} \mathrm{O}_{2} \mathrm{mg}^{-1}$.

Total protein extraction and antioxidant enzyme activity: catalase, ascorbate peroxidase, glutathione reductase, and superoxide dismutase. Total protein was extracted from the treated seeds at 0 (initial time), 6, 12, 24, 48, 72, and $96 \mathrm{~h}$ under native conditions (Lara-Nuñez et al., 2006 [RC5]) and homogenized in an extraction buffer $\left(100 \mathrm{mg} \mathrm{mL}^{-1}\right)$, containing $50 \mathrm{mM}$ potassium phosphate $(\mathrm{pH} 7.0)$ with $1 \mathrm{mM}$ ethylenediaminetetraacetic acid (EDTA), and 1\% polyvinylpolypyrrolidone for catalase (CAT), superoxide dismutase (SOD) and glutathione reductase (GR) activity or with 1 $\mathrm{mM}$ ascorbate for ascorbate peroxidase (APX) activity. The homogenate was centrifuged at $3,000 \times \mathrm{g}$ for $10 \mathrm{~min}$ at $4{ }^{\circ} \mathrm{C}$ to remove cellular debris, and the protein concentration was determined with a Bradford assay (Bradford, 1976).

CAT (EC 1.11.1.6) activity was determined by assessing the consumption of $\mathrm{H}_{2} \mathrm{O}_{2}$ (extinction coefficient $39.4 \mathrm{mM}^{-1}$ $\mathrm{cm}-1$ ) at $240 \mathrm{~nm}$ for $3 \mathrm{~min}$ (Aebi, 1984) in $1 \mathrm{~mL}$ reaction volume containing $50 \mathrm{mM}$ potassium phosphate buffer $(\mathrm{pH}$ 7.0), $10 \mathrm{mM} \mathrm{H}_{2} \mathrm{O}_{2}$, and $50 \mu \mathrm{g}$ of protein extract. The data are presented as the mean of three replicates each from three independent experiments with activity expressed as $\mu \mathrm{mol}$ $\min ^{-1}$ mg protein ${ }^{-1}$.

APX (EC 1.11.1.11) activity was determined by the decrease in absorbance over $1 \mathrm{~min}$ at $290 \mathrm{~nm}$ (extinction coefficient $\left.2.8 \mathrm{mM}^{-1} \mathrm{~cm}^{-1}\right)$ in $1 \mathrm{~mL}$ of a reaction medium containing $50 \mathrm{mM}$ potassium phosphate buffer ( $\mathrm{pH} 7.0), 0.5$ $\mathrm{mM}$ ascorbic acid (ASC), $0.1 \mathrm{mM} \mathrm{H}_{2} \mathrm{O}_{2}$, and $25 \mu \mathrm{g}$ protein extract (Jiang and Zhang, 2002). A blank was included for the low, non-enzymatic oxidation of ASC by $\mathrm{H}_{2} \mathrm{O}_{2}$. The data are presented as the mean of three replicates each from three independent experiments with activity expressed as $\mu \mathrm{mol}$ $\mathrm{min}^{-1} \mathrm{mg}$ protein ${ }^{-1}$.

GR (EC 1.6.4.2) activity was determined by monitoring the oxidation of nicotinamide adenine dinucleotide phosphate (NADPH) at $340 \mathrm{~nm}$ (extinction coefficient $6.2 \mathrm{mM}^{-1}$ $\mathrm{cm}^{-1}$ ) for $3 \mathrm{~min}$ in $1 \mathrm{~mL}$ reaction volume containing $50 \mathrm{mM}$ potassium phosphate buffer ( $\mathrm{pH}$ 7.8), $2 \mathrm{mM}$ EDTA, $0.5 \mathrm{mM}$ glutathione disulfide, and $50 \mu \mathrm{g}$ of protein extract. The reaction was initiated by adding $0.15 \mathrm{mM}$ NADPH solution and evaluated every 20 seconds for $5 \mathrm{~min}$. A blank was included for the background absorbance at $340 \mathrm{~nm}$ without NADPH (Jiang and Zhang, 2002). The data are presented as the mean of three replicates each from three independent experiments with activity expressed as $\mu \mathrm{mol} \mathrm{min}{ }^{-1} \mathrm{mg}$ protein ${ }^{-1}$.

SOD (EC 1.15.1.1) activity was assayed by monitoring the autoxidation of epinephrine (adenochrome) as described by Misra and Fridovich (1972) using an extinction coefficient of $4.020 \mathrm{M}^{-1} \mathrm{~cm}^{-1}$. Activity was measured in $0.5 \mathrm{~mL}$ reaction volume containing $50 \mathrm{mM}$ sodium carbonate buffer (pH 10.2), $0.5 \mathrm{mM}$ EDTA, $50 \mu \mathrm{g}$ extracted protein, and 0.5 $\mathrm{mL}$ of epinephrine $\left(10 \mathrm{mg} \mathrm{mL}^{-1}\right.$ dissolved in $10 \mathrm{mM} \mathrm{HCl}$, $\mathrm{pH}$ 2.0). After the lag phase (2-3 min), the autoxidation of epinephrine was determined at $480 \mathrm{~nm}$ every $10 \mathrm{~s}$ for $3 \mathrm{~min}$. Activity is reported as adenochrome $\mathrm{min}^{-1} \mathrm{mg}$ protein ${ }^{-1}$.

The superoxide levels $\left(\mathrm{O}_{2}^{-}\right)$are expressed as $\mu \mathrm{mol}$ per $\mathrm{mg}$ protein and were calculated by dividing the highest ab- 


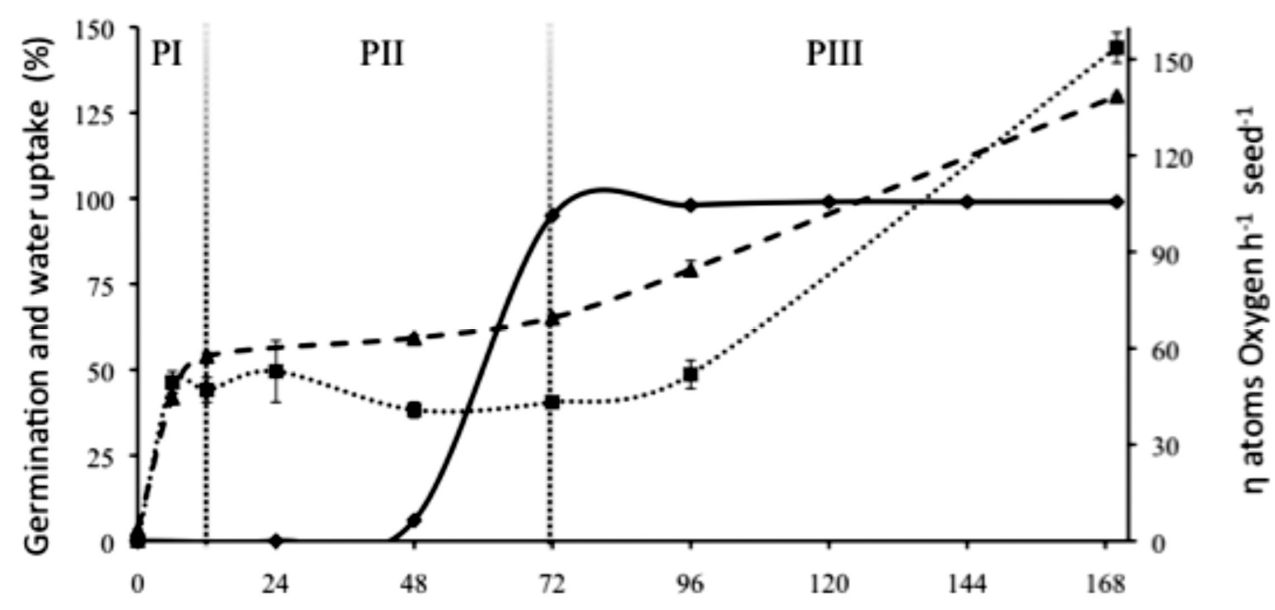

Imbibition time (h)

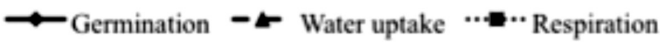

Figure 3. Alvaradoa amorphoides germination phases (PI, PII, and PIII), water uptake, and respiration under controlled conditions.

sorbance of the data previous to the lag phase by the extinction coefficient and the milligrams of protein.

Statistical analysis. All data were analyzed by two-factor analyses of variance, with water potential and time as the two factors. The data was first tested for normality and homoscedasticity and germination data were transformed to arcsine. The statistical analysis was performed with the STATISTICA software package v 7.0 (Statsoft, Inc., USA).

\section{Results}

Seed germination in the field. The mean seed germination at the eight field sites ( 1 to 8 ) was $42 \%$, which does not take into account the soil humidity or geomorphology of the site. Sites 2, 3, and 5 showed the highest seed germination rates $(63,61$, and $60 \%$, respectively) and had soil RH values of 46, 50, and 23\%, respectively (Table 1). Sites 1, 4, and 6 had germination rates of 45,32 , and $35 \%$, respectively, with soil RHs of 45,46 , and $28 \%$, respectively. The lowest rate of seed germination was found at sites 7 (9\%) and $8(21 \%)$, which had soil RHs of 59 and $41 \%$, respectively (Table 1 ).

Oxygen consumption, water uptake, and germination rate. Figure 3 shows the three phases of germination, water uptake, and respiration as described by Bewley (1997). Phase I was from 0 to $12 \mathrm{~h}$, which corresponded to a $30 \%$ increase in the water uptake. In this phase, the detection of oxygen consumption demonstrated that seed metabolism had restarted (Bradford, 1995; Bewley, 1997; Nonogaki et al., 2010). Phase II, known as the stationary phase, was from 12 to 72 $\mathrm{h}$ of imbibition, in which no detectable increase in water uptake or oxygen consumption occurred. In this phase, germination sensu stricto is activated, beginning with radicle protrusion (Bradford, 1995; Nonogaki, et al., 2010). Phase
III, or post-germination, occurred after $72 \mathrm{~h}$, when the germination rate no longer changed, and both respiration and water uptake increased due to the presence of radicles in the germinated seeds (Figure 3).

Seeds that were germinated at a water potential of -0.5 MPa showed a 24 h delay. However, by $96 \mathrm{~h}$ they had reached the same high rate of germination as the control seeds. A water potential of $-1.0 \mathrm{MPa}$ inhibited germination by $84 \%$, and the seeds did not begin to germinate until $96 \mathrm{~h}$. The lowest water potential of $-1.5 \mathrm{MPa}$ inhibited germination completely (Figure 4A). The seeds that imbibed the negative water potentials took up significantly less water (Figure 4B). This decrease in the rate of imbibition was observed from $12 \mathrm{~h}$ onward, and the same reduced rate of water uptake was maintained during the entire observation period (Figure 4B).

Respiration, or oxygen consumption, began after $6 \mathrm{~h}$ of imbibition for all treatments with no significant differences observed between them (Figure 4C). In fact, no differences were observed between the treatments for the oxygen consumption of the seeds during Phases I and II of germination. After $72 \mathrm{~h}$ (Phase III) of water uptake, the oxygen consumption began to increase only in the control seeds. Although the seeds germinated at the - $0.5 \mathrm{MPa}$ water potential (80-90\%), no increase in respiration or water uptake was observed.

ROS levels and antioxidant enzyme activity during germination. Dry seeds displayed $\mathrm{H}_{2} \mathrm{O}_{2}$ and $\mathrm{O}_{2}$ - production as well as CAT, SOD, and GR enzyme activity (initial times are shown in Figure 5), but no APX activity was observed. At no time were there differences in the levels of $\mathrm{H}_{2} \mathrm{O}_{2}$ and $\mathrm{O}_{2}$ - when the seeds were germinated at negative water potentials $(-0.5$ and -1.0 MPa; Figure 5A, B). In addition, the water potential 


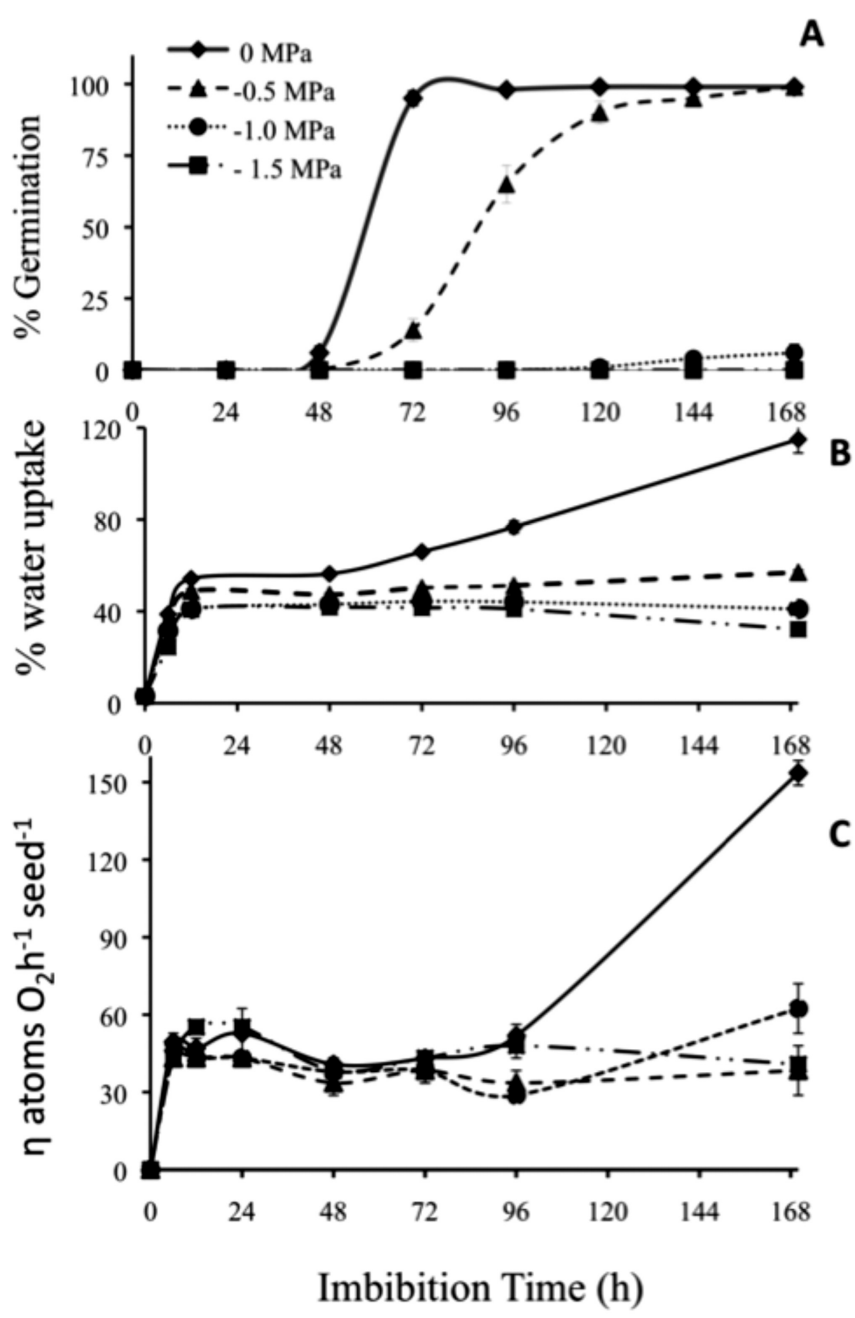

Figure 4. Alvaradoa amorphoides seeds exposed to water potentials of $0,-0.5,-1.0$, and $-1.5 \mathrm{MPa}$. A) Germination (\%); B) water uptake (\%); and C) rate of respiration ( $\eta$ atoms of oxygen seed ${ }^{-1}$ hour $\left.^{-1}\right)$. $\mathrm{N}=8$, low case different letters mean significant difference (Tukey test, $P<0.05$ ).

did not modify the CAT, SOD, or GR activities $(P>0.05)$. However, at $72 \mathrm{~h}$, the CAT activity of seeds at the $-0.5 \mathrm{MPa}$ water potential was significantly less than that of the control seeds $(0 \mathrm{MPa})$. The different dynamics of enzyme activity were related to the imbibition time, but were not caused by the treatments. APX activity was observed until $48 \mathrm{~h}$, and both the -0.5 and $-1.0 \mathrm{MPa}$ water potentials resulted in a significant decrease in activity $(P<0.05$; Figure 5E).

\section{Discussion}

Germination under field conditions. In this study, Alvaradoa amorphoides seeds showed an overall mean germination rate of $42 \%$, but the germination rates varied between the eight sites independently of the soil RH and geomorphology (Table 1). At one site with a high soil RH (7) we recorded only a $9 \%$ germination rate. Conversely, another site that had a low RH (5) showed higher germination rates (60\%). These results suggest that $A$. amorphoides seeds may tolerate reduced soil humidity levels, which is in agreement with other studies of dry tropical forest species (e.g. Khurana and Singh, 2001). However, the heterogeneous soil conditions and the presence of rocks in the Xochicalco region (shallow soil, $5 \mathrm{~cm}$ ) may play an important role in determining seed germination rates. According to Evans and Etherington (1990), plant species have different tolerance levels to dehydration depending on the soil water availability of their native habitat. These authors suggested that each species has a critical hydration level for successful germination. Germination, water uptake, and oxygen consumption at negative water potentials under laboratory conditions. The Alvaradoa amorphoides seeds showed the same three-phase process of water uptake during imbibition that has been previously described for orthodox seeds with a permeable seed coat (Bradford, 1995). These three phases were evident in both the germination times and oxygen consumption (Figure 3). When the seeds were germinated under conditions of negative water potential, germination was almost abolished at the -1.0 and $-1.5 \mathrm{MPa}$ water potentials, and it was delayed at the -0.5 MPa water potential. As Bradford (1995) described, Phase II (plateau phase) is considered the period of germination sensu stricto. The length of this phase is sensitive to environmental factors, such as water availability that affect the timing and extent of germination. Although seed germination was diminished by $80 \%$ to nearly $100 \%$ at water potentials of -1.0 and $-1.5 \mathrm{MPa}$, respectively, when these seeds were transferred to water $(0 \mathrm{MPa})$, they were still viable and able to germinate $(95 \pm 2 \%$ and $78 \pm 3 \%$, respectively; Hernández-Pérez observation). Seed germination delay or inhibition caused by negative water potentials has also been observed in sorghum (Lobato et al., 2008), red beet (Gummerson, 1986), some species of the genus $P i$ per (Daws et al., 2002), Bulnesia retama (Rodríguez et al., 2007), and Ficus aurea (Swagel et al., 1997).

Water uptake by the seeds was reduced at the three low water potentials tested (Figure 4B). The treated seeds imbibed as much as the control seeds up to $12 \mathrm{~h}$, then stabilized, and most importantly, did not display the second water uptake increase that the control seeds showed at $48 \mathrm{~h}$. However, the seeds treated at the $-0.5 \mathrm{MPa}$ water potential were able to reach $100 \%$ of the control seed germination rate after $96 \mathrm{~h}$. The respiratory rate was also monitored during germination due to the importance of this process in maintaining energy metabolism in the seeds and as a major source of ROS (Møller, 2001; Bailly, 2004; Macherel et al., 2007; Noctor et al., 2007). In the control seeds, the respiratory rate encompassed three phases (Patanè et al., 2006). At the negative water potentials, the respiration rate showed only two phases, the first respiratory burst followed by the plateau phase that extended to $170 \mathrm{~h}$. The seeds treated at the $-0.5 \mathrm{MPa}$ water potential had a delay in germination, which 

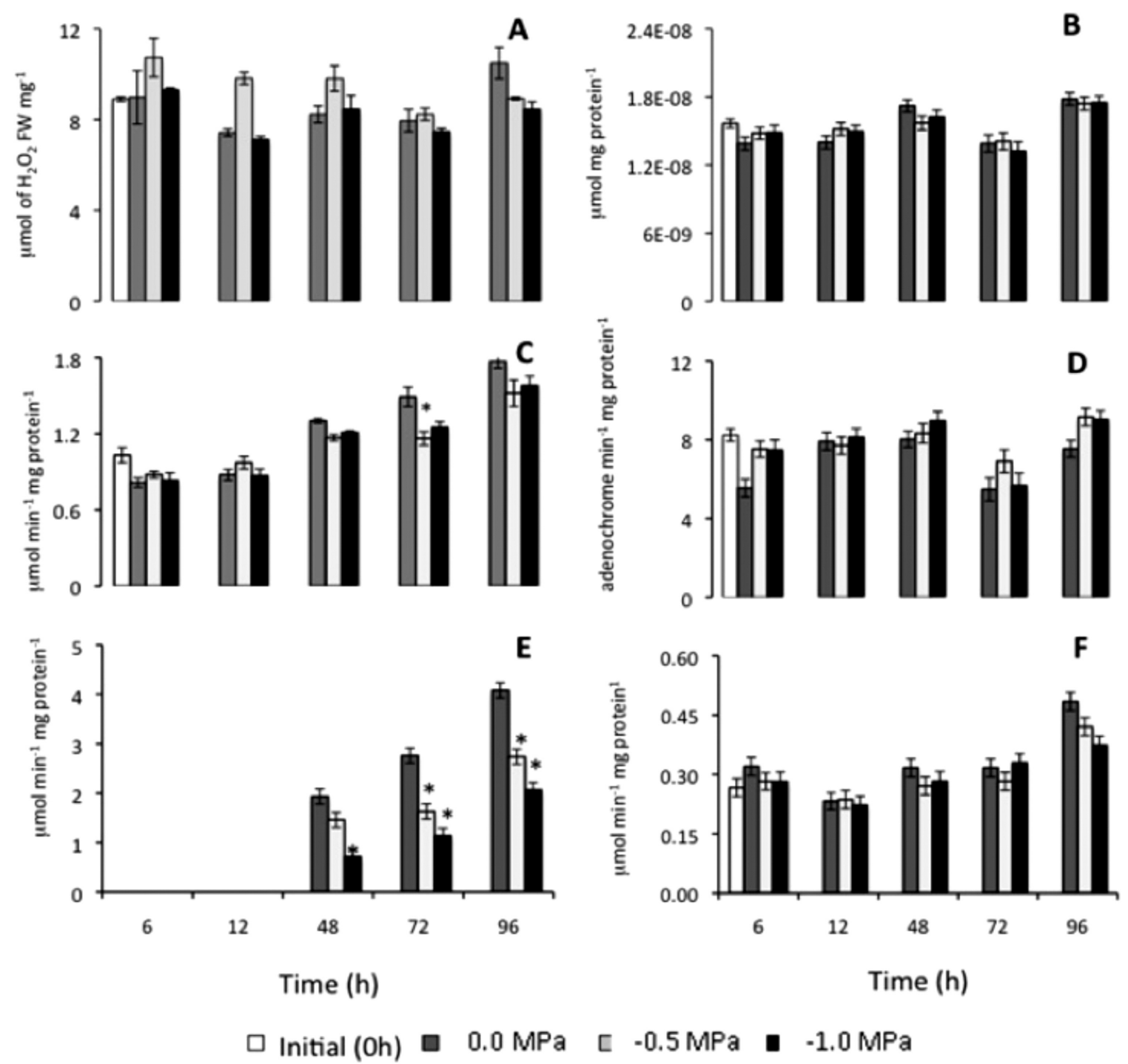

Figure 5. Reactive oxygen species (ROS) production and antioxidant enzyme activity in Alvaradoa amorphoides seeds exposed to three negative water potentials. A) $\mathrm{H}_{2} \mathrm{O}_{2}$ and B) superoxide production; C) catalase (CAT), D) superoxide dismutase (SOD), E) ascorbate peroxidase (APX), and F) glutathione reductase (GR) activity. Data are the mean of at least eight replicates, and bars represent the standard error. *Denotes statistical differences (Tukey test, $P<0.05)$ with respect to the control seeds $(0 \mathrm{MPa})$ at the specific time.

confirmed that seed respiration or the metabolic energy supply was a limiting factor in the timing of germination, as reported previously by Dahal et al. (1996) for tomato seeds. This finding was also supported by the observation that seeds exposed to the lowest water potentials (-1.0 and -1.5 $\mathrm{MPa}$ ) were able to germinate when they were transferred to pure water. Dahal et al. (1996) suggested that the reduced respiration rate at low water potentials is a consequence of rather than the cause of the germination rate.

ROS and antioxidant enzyme activity during germination. It is known that in orthodox seeds, imbibition starts the reactivation of mitochondrial respiration and seed reserve mobilization, and these processes can generate an excess of ROS (Tommasi et al., 2001; Bailly, 2004; Bailly et al., 2008; Kranner et al., 2010). However, our results showed that there were no significant differences over time in the levels of either $\mathrm{H}_{2} \mathrm{O}_{2}$ or $\mathrm{O}_{2}$ - between the seeds that imbibed at a low water potential and the control seeds. These results are in contrast to the findings of studies with crop seeds, which showed that $\mathrm{H}_{2} \mathrm{O}_{2}$ increased during Phase I of germination (Puntarulo et al., 1991) [RC7] Bellani et al., 2002). One possible explanation for the lack of change in ROS production could be a tight control by their antioxidant system (Bailly et al., 2008; Miller et al., 2010).

Although the $\mathrm{H}_{2} \mathrm{O}_{2}$ levels did not increase significantly, an increase in CAT activity was detected in the control seeds, which coincided with the second respiratory burst that was observed in these seeds (Bailly, 2004; Bailly et al., 2008). With the exception of an increase over time in the control seeds, CAT activity was unaffected by the water potential. 
It has been reported that orthodox seeds enter the resting stage with neither an ASC content nor ascorbate peroxidase activity, and the ascorbate-glutathione (ASH-GSH) cycle begins to be active during germination Phase II or III when the radicles protrude and germination is completed (De Tullio and Arrigoni, 2003). Our study confirmed this finding in Alvaradoa amorphoides; the activity of ascorbate peroxidase began after $48 \mathrm{~h}$ of imbibition for all treatments. Interestingly, the seeds from the low water potential treatments (-0.5 and -1.0 MPa; - 1.5 MPa was not included since seeds germination showed $100 \%$ inhibition) had significantly less activity $(P<0.05$ [AR8] [RC9]) than the control seeds. Other authors have reported that orthodox seeds do not have APX activity (Cakmak et al., 1993; Tommasi et al., 2001, De Tullio and Arrigoni, 2003). Therefore, even though we observed GR activity, it seems that the ASC-GSH cycle was not functional during Phase I of germination. It is possible that the ASC content and APX activity are related to Phases II and III of germination when the radicles begin to protrude. It is known that ASC is required for the activity of dioxygenases, which are involved in the synthesis of plant hormones such as ethylene, gibberellic acid, and abscisic acid, among others, which are required for the cell cycle and cell division in radicles (Nambara and Marion-Poll, 2003). The low APX activity in the treated seeds might explain the lower germination rates of these seeds.

\section{Conclusions}

In summary, it is clear that when Alvaradoa amorphoides is exposed to a low water potential (-0.5 MPa), germination is delayed and extends to Phase II, which is also true for the seeds exposed to water potentials of -1.0 and $-1.5 \mathrm{MPa}$. Even though the seeds did not germinate under these conditions, they were able to do so when they were transferred to plain water. This behavior may explain why there were no differences in the germination rates observed in the field related to the soil humidity or landscape. On the other hand, the low water potentials did not affect antioxidant enzyme activity, and intriguingly there was no oxidative burst when germination began, suggesting that $A$. amorphoides tightly regulates the ROS levels.

Based on our results, Alvaradoa amorphoides is a tolerant species that can endure water stress during seed germination by extending Phase II and tightly maintaining control of stress response mechanisms, such as ROS production and antioxidant enzyme activity.

\section{Acknowledgments}

This paper constitutes a partial fulfillment of the Graduate Program in Biological Sciences of the Universidad Nacional Autónoma de México (UNAM). V. Hernández-Pérez acknowledges the scholarship and financial support pro- vided by the National Council of Science and Technology (CONACyT) and UNAM. We also acknowledge to the two anonymous reviewers for their valuable comments and suggestions.

\section{Literature cited}

Aebi H. 1984. Catalase in vitro. In: Parker L. Ed. Methods in Enzymology, Vol. 105, pp. 121-126, Academic Press, Orlando.

Bailly C. 2004. Active oxygen species and antioxidants in seeds biology. Seed Science Research 14:93-107.

Bailly C., El-Maarouf-Bouteau H. and Corbineau F. 2008. From intracellular signaling networks to cell death: the dual role of reactive oxygen species in seed physiology. Comptes Rendus Biologies 331:806-814.

Baskin C.C. and Baskin J.M. 1998. Seeds: Ecology, Biogeography and Evolution of Dormancy and Germination. Academic Press, San Diego.

Bellani L.M., Guarnieri M. and Scialabba A. 2002. Differences in the activity and distribution of peroxidases from three different portions of germinating Brassica oleracea seeds. Physiologia Plantarum 114:102-108.

Bewley J.D. and Black M. 1985. Seeds: Physiology of Development and Germination. $2^{\text {nd }}$ edition. Plenum Press, New York.

Bewley J.D. 1997. Seed Germination and Dormancy. The Plant Cell 9:1055-1066.

Bradford M.M. 1976. A rapid and sensitive method for the quantitation of microgram quantities of protein utilizing the principle of protein-dye binding. Analytical of Biochemistry 72:248-254.

Bradford K.J. 1995.Water relations in seed germination. In: Kigel J. and Galili G. Eds. Seed: Development and Germination, pp. 351-396, Marcel Dekker, New York.

Bullock S.H. and Solis-Magallanes J.A. 1990. Phenology of canopy trees of a tropical deciduous forest in Mexico. Biotropica 22:22-35.

Cakmak I., Strbac D. and Marschner H. 1993. Activities of hydrogen peroxide-scavenging enzymes in germinating wheat seeds. Journal of Experimental Botany 44:127-132.

Ceccon E. and Hernández P. 2009. Seed rain dynamics following disturbance exclusion in a secondary tropical dry forest in Morelos, Mexico. Revista de Biología Tropical 57:257-269.

Ceccon E., Huante P. and Rincón E. 2006. Abiotic factors influencing tropical dry forests regeneration. Brazilian Archives of Biology and Technology 49: 305-312.

Dahal P., Kim N.S. and Bradford K.J. 1996. Respiration and germination rates of tomato seeds at suboptimal temperatures and reduced water potentials. Journal of Experimental Botany 47:941-947.

Daws M.I, Burslem D.F.R.P., Crabtree L.M., Kirkman P., Mullins C.E. and Dalling J.W. 2002. Differences in seed germination responses may promote coexistence of four sympatric Piper species. Functional Ecology 16:258-267.

De Tullio M.C. and Arrigoni O. 2003. The ascorbic acid system in seeds: to protect and to serve. Seed Science Research 13:24960.

Engelbrecht B.M.J., Dalling J.W., Pearson T.R.H., Wolf R.L., Gálvez D.A., Koehler T., Tyree M.T. and Kursar T.A. 2006. Short dry spells in the wet season increase mortality of tropical pioneer seedlings. Oecologia 148:258-269. 
Evans C.E. and Etherington J.R. 1990. The effect of soil water potential on seed germination of some British plants. New Phytologist 115:539-548.

Garwood N. 1983. Seed germination in a seasonal tropical forest in Panama: a community study. Ecological Monographs 53:159181.

Gummerson R.J. 1986. The effect of constant temperatures and osmotic potentials on the germination of Sugar Beet. Journal of Experimental Botany 37:729-741.

Hegarty T.W. and Ross H.A. 1978. Some characteristic of the water-sensitive process in the inhibition of germination by water stress. Annals of Botany 42:1223-1226.

Jana S. and Choudhuri M.A. 1982. Glycolate metabolism of three submerged aquatic angiosperm during ageing. Aquatic Botany 12:345-354.

Janzen D.H. 1988. Tropical dry forests: the most endangered major tropical ecosystem. In: Wilson E.O. Ed. Biodiversity, pp.130137, National Academic Press, Washington, D.C.

Jiang M. and Zhang J. 2002. Water stress-induced abscisic acid accumulation triggers the increased generation of reactive oxygen species and up-regulates the activities of antioxidant enzymes in maize leaves. Journal of Experimental Botany 53:2401-2410.

Khurana E. and Singh J.S. 2001. Ecology of seed and seedling growth for conservation and restoration of tropical dry forest: a review. Environmental Conservation 28:39-52.

Kranner I., Minibayeva F.V., Beckett R.P. and Seal C.E. 2010. What is stress? Concepts, definitions and applications in seed science. New Phytologist 188:655-673.

Krishnan P., Nagarajan S. and Moharir A.V. 2004. Thermodynamic characterization of seed deterioration during storage under accelerated ageing conditions. Biosystems Engineering 89:425433.

Lara-Nuñez A., Romero-Romero T., Ventura J.L., Blancas V., Anaya A.L. and Cruz-Ortega R. 2006. [AR10] [RC11] Allelochemical stress causes inhibition of growth and oxidative damage in Lycorpersicon esculentum Mill. Plant Cell and Enviroment 29:2009-2016.

Lobato A.K.S., Oliveira N.C.F., Costa R.C.L., Santos F.B.G., Silva F.K.S., Cruz F.J.R., Abboud A.C.S. and Laughinghouse H.D. 2008. Germination of sorghum under the influences of water restriction and temperature. Agricultural Journal 3:220-224.

Macherel D., Benamar A., Avelange-Macherel M.H. and Tolleter D. 2007. Function and stress tolerance of seed mitochondria. Physiologia Plantarum 129:233-241.

Michel B.E. and Radcliffe D. 1995. A computer program relating solute potential to solution composition for five solutes. Agronomy Journal 87:126-130.

Miller G., Suzuki N., Ciftci-Yilmaz S. and Mittler R. 2010. Reactive oxygen species homeostasis and signalling during drougtht and salinity stresses. Plant, Cell and Environment 33:453-467.

Misra H.P. and Fridovich I. 1972. The role of superoxide anion in the autoxidation of epinephrine and a simple assay for superoxide dismutase. The Journal of Biology Chemistry 247:3170-3175.

Møller I.M. 2001. Plant mitochondria and oxidative stress: electron transport, NADPH turnover, and metabolism of reactive oxygen species. Annual Review of Plant Physiology and Plant Molecular Biology 52:561-591.

Murphy P.G. and Lugo A.E. 1986. Ecology of tropical dry forest. Annual Review of Ecology and Systematics 17:67-88.

Nambara E. and Marion-Poll A. 2003. ABA action and interaction in seeds. Trends in Plant Science 8:213-217.

Noctor G., De Paepe R. and Foyer C.H. 2007. Mitochondrial redox biology and homeostasis in plants. Trends in Plant Science 12:125-134.

Nonogaki H., Bassel G.W. and Bewley J.D. 2010. GerminationStill a mystery. Plant Science 179:574-581.

Patanè C., Cavallaro V., Avola G. and D'Agosta G. 2006. Seed respiration of sorghum [Sorghum bicolor (L) Moench] during germination as affected by temperature and osmoconditioning. Seed Science Research 16:251-260.

Puntarulo S., Galleano M., Sanchez R.A. and Boveris A. 1991. [AR12] [RC13] Superoxide anion and hydrogen peroxide metabolism in soybean embryonic axes during germination. Biochimica et Biophysica Acta 1074:277-283.

Rodríguez R.M.F., Sosa L.R., Fernández E.A., Reale M.I. and Villarreal V. 2007. Efecto del estrés hídrico a distintas temperaturas sobre la germinación de semillas de Bulnesia retama (Gill. ex. Hook.) Griseb. - Zigofiláceas - en San Luis, Argentina (Con 3 Tablas y 2 Figuras). Phyton (BuenosAires) 76:5-17.

Salazar R. and Soihet C. 2001. Manejo de semillas de 75 especies forestales de América Latina, Volumen II. Manual Técnico No. 48. Centro Agronómico Tropical de Investigación y Enseñanza, Turrialba.

Siebe C., Jahn R., Stahr K. 1996. Manual para la Descripción y Evaluación Ecológica de Suelos en el Campo. Publicación Especial 4. Sociedad Mexicana de la Ciencia del Suelo, A.C., Chapingo.

Swagel E.N., Bernhard A.H. and Ellmore G.S. 1997. Substrate water potential constraints on germination of the strangler fig Ficus aurea (Moraceae). American Journal of Botany 84:716722.

Tommasi F., Paciolla C., de Pinto M.C. and De Gara L. 2001. A comparative study of glutathione and ascorbate metabolism during germination of Pinus pinea seeds. Journal of Experimental Botany 52:1647-1654.

Trejo I. and Dirzo R. 2000. Deforestation of seasonally dry tropical forest: a national and local analysis in Mexico. Biological Conservation 94:133-142.

Xiong L. and Zhu J.K. 2002. Molecular and genetic aspects of plant responses to osmotic stress. Plant, Cell and Environment 25:131-139. 